\title{
Palynological studies on some medicinal mallows from Punjab, India.
}

Paramjeet Cheema

IAS \& Allied Services Training Centre, Punjabi University, Patiala-147002, India

Received: 2/23/2018; Accepted: 2/28/2018

\begin{abstract}
Seven plant species belonging to family Malvaceae were subjected to standard palynological studies in order to generate data for pollen characterization and identification of medicinally important mallows from Punjab, NW India. Pollen grains of this family are unique being porate and echinate having isolated spines. Pollen grains are either 3-porate, 6-7 porate or polypantoporate with oblate spheroidal shape and reticulate or semitectate reticulate exine. Based on various palynological parameters like the range in size, shape, aperture, exine thickness, ornamentation, etc. key to identification of presently studied taxa has been evolved.
\end{abstract}

Key words: Echinate, Malvaceae, Palynology, Pollen grain, Oblate spheroidal, Reticulate.

\section{Introduction}

The Malvaceae or mallow family is a cosmopolitan family of herbs, shrubs, climber and small trees with a wider distribution in the tropical regions. This family comprises some 110 genera and over 2000 species, divided into six tribes: Malopeae, Malveae, Hibiscieae, Abutilieae, Ureneae and Decaschistieae (Hutchinson, 1967; Bates, 1968; Fryxell, 1975 \& 1988; La Duke \& Doebley, 1995; Krebs, 1994, a \& b).

The study of pollen is an important area of research because the pollen morphological characters such as the shape, apertural pattern and exine configuration are very conservative features for the taxonomic assessment of the plants (Perveen 2006, Bera et al., 2007, Keshavarzi et al., 2012). According to Adekanmbi (2009) more often these characters are species specific and are used to identify the source plants during various studies. Owing to the high economic value of some genera of the Malvaceae, several studies from different perspectives have been carried out in this family. Pollen morphology of selected genera of Hibiscus and Abutilon from Pakistan have been investigated by Perveen et al., (1994), Bibi et al., (2008) and Shaheen et al., (2009).

This paper aims to analyse some members of the family using LM techniques. Various parameters such as the pollen shape, range in pollen size, exine ornamentations, apertures, etc. have been of considerable help in identification of the taxon. Based on these features a key to identification of the presently studied species has been evolved. The data generated alongwith other morphological characters will be helpful in the identification of these species.

\section{Materials and Methods}

For the present investigation plants at flowering stage were collected from various localities representing different habitats like boundaries of the fields, crop fields and waste places in Punjab, NW India (Table 1). Pollen morphology was studied by acetolysis method (Erdtman 1952). The matre anther lobes were crushed in $70 \%$ ethyl alcohol and then centrifuged. Acetolysis of pollen grains was done with 9 parts acetic anhydride with 1 part concentrated sulfuric acid. Then these were washed with glacial acetic acid followed by mounting on slide in glycerol. Range in pollen size was determined by making observation on unacetolysed pollen grains. Medicinal importance of the species mentioned is based on the available literature.

For Pollen terminology Erdtman (1952), Erdtman et al., (1961), Nair (1965, 1966) and Reitsma (1970) have been followed. Shape of the pollen grains is based on measurements of polar axis $(\mathrm{P})$ and equatorial diameter $(\mathrm{E})$ and the resulting $\mathrm{P} / \mathrm{E}$ ratio. Voucher specimens of the plants have been deposited in the Herbarium, Department of Botany, Punjabi University, Patiala (PUN). Photographs are at magnification $\times 1080$ taken with Olympus light microscopes

\footnotetext{
*Corresponding Author:

Paramjeet Cheema,

Associate Professor,

IAS \& Allied Services Training Centre,

Punjabi University, Patiala, India.

E-mail: dr_paramjeet@rediffmail.com 
Table 1. Investigated taxa with their common name, habitat, habit, flowering period and accession number (PUN)

\begin{tabular}{|c|c|c|c|c|}
\hline Name of the species & Common name/s & Locality/Habitat & Habit/ Flowering period & $\begin{array}{l}\text { Accession } \\
\text { number }\end{array}$ \\
\hline Abutilon indicum (Linn.) Sweet. & $\begin{array}{l}\text { Indian mallow, Atibala, Kantika, } \\
\text { Kangi, Pili booti }\end{array}$ & Patiala/ Waste places & $\begin{array}{l}\text { Shrub/ March - May, } \\
\text { September - November }\end{array}$ & 33741,33742 \\
\hline Hibiscus vitifolius Linn. & $\begin{array}{l}\text { Grape leaved mallow, Van } \\
\text { kapus, Jangali kapah }\end{array}$ & Sangrur/ Waste places & $\begin{array}{l}\text { Perennial herb/ July - } \\
\text { October }\end{array}$ & 33743,33744 \\
\hline Malwa parviflora Linn. & Cheese weed mallow, Panirak & Sangrur/ Waste places & $\begin{array}{l}\text { Annual herb/ February - } \\
\text { April }\end{array}$ & 34431,34432 \\
\hline $\begin{array}{l}\text { Malvastrum coromandelianum } \\
\text { (Linn.) Garcke }\end{array}$ & $\begin{array}{l}\text { False mallow, Broom weed, } \\
\text { Clock plant, Kharenti }\end{array}$ & $\begin{array}{l}\text { Bathinda/ } \\
\text { Waste places, crop fields }\end{array}$ & $\begin{array}{l}\text { Perennial herb/ February - } \\
\text { April }\end{array}$ & 32046,32047 \\
\hline Sida acuta Burm.f. & $\begin{array}{l}\text { Common wireweed, Bala, } \\
\text { Kharenti }\end{array}$ & Patiala/ Waste places & $\begin{array}{l}\text { Perennial herb/ September } \\
\text { - November }\end{array}$ & 33745,33746 \\
\hline Sida cordata (Burm.f.) Borss. & $\begin{array}{l}\text { Country mallow, Bhumibala, } \\
\text { Faridbuti }\end{array}$ & Faridkot/ Along hedges & $\begin{array}{l}\text { Perennial herb/ March - } \\
\text { April, August - October }\end{array}$ & 33747,33748 \\
\hline Sida cordifolia Linn. & $\begin{array}{l}\text { Country mallow, Bala, Kungyi, } \\
\text { Simak }\end{array}$ & Barnala/ Waste places & $\begin{array}{l}\text { Perennial herb/ March - } \\
\text { April, August - November }\end{array}$ & 33749,33750 \\
\hline
\end{tabular}

\section{Results and Discussion}

Data on pollen size, shape, aperture, exine and other pollen characters pertaining to 7 species belonging to family Malvaceae has been provided in Table 2. Pollen grains in presently studied 7 species are oblate spheroidal, porate (except for Malvastrum coromandelianum), with reticulate exine (except for Sida cordifolia) and are echinate.

Abutilon indicum has been used extensively as a home remedy in traditional Chinese and Indian medicine. The medicinal properties of Abutilon indicum include anti-inflammatory, lipid lowering, analgesic, antioxidant, antibacterial, antidiabetic, hepato protective, antimycotic, anti-diarrhoeal and anti-convulsant. Pollen grain is oblate spheroidal, 3porate with biggest pore size $9.09 \times 6.55 \mu \mathrm{m}$ (Figs. 12). For the same species from Pakistan Shaheen et al., (2009) recorded the pollen grains with suboblate shape and 3-zonoporate nature of pores. Jain \& Nanda (1966-67) reported pollen grains for the species from Pillani as spheroidal, 3-colporate with small sized spines $(3.80 \mu \mathrm{m})$.

Hibiscus vitifolius roots are used for the treatment of jaundice in the folklore system of medicine in India (Samuel et al., 2012). It has biggest pollen $(151.16 \times 149.45 \mu \mathrm{m})$ with longest spines
(24.85 $\mu \mathrm{m})$ among the presently studied species (Fig. 3).

Malva parviflora leaf extracts possess antiinflammatory and antioxidant activities. Plant has oblate spheroidal, polypantoporate pollen grains with smallest pores $(2.94 \times 2.94 \mu \mathrm{m})$ and reticulate exine pattern (Fig. 4). The studies by Naggar (2004) for the species from Egypt revealed pollen grains as polypantoporate but exine pattern as verrucate. Studies by Rao \& Shukla (1975) reported pollen bigger $(84.0 \mu \mathrm{m})$ in diameter with wider pore $(4.0$ $\mu \mathrm{m})$ but smaller spines $(6.0 \mu \mathrm{m})$ as compared to the presently studied species. What are the inferences..?

Malvastrum coromandelianum plant parts are used by numerous tribal populations throughout the world. In Indian system of medicine the plant is reported as an anti- inflammatory, analgesic, and antidysenteric (Sanghai et al., 2013). The pollen are inaperturate, oblate spheroidal with reticulate exine having second largest spines $(12.12 \mu \mathrm{m})$ among the presently studied species (Fig. 5).

Sida acuta whole plant decoction is used as a treatment for fever and the juice of the plant is used to treat indigestion. It has 6-7 pantoporate pollen grains with pollen size $87.74 \times 84.41 \mu \mathrm{m}$ (Fig. 6).

Table 2. Pollen morphological details of the investigated taxa

\begin{tabular}{|c|c|c|c|c|c|c|c|}
\hline Name of species & $\begin{array}{l}\text { Average size } \\
(\mu \mathrm{m})\end{array}$ & Shape & Aperture & $\begin{array}{l}\text { Pore } \\
\text { diameter } \\
(\mu \mathrm{m})\end{array}$ & $\begin{array}{l}\text { Exine } \\
\text { ornamentation }\end{array}$ & $\begin{array}{l}\begin{array}{l}\text { Spine } \\
\text { size } \\
(\mu \mathrm{m})\end{array} \\
\end{array}$ & $\begin{array}{l}\begin{array}{l}\text { Exine } \\
\text { thickness }(\mu \mathrm{m}) /\end{array} \\
\text { Figure }\end{array}$ \\
\hline $\begin{array}{l}\text { Abutilon indicum } \\
\text { (Linn.) Sweet. }\end{array}$ & $65.54 \times 63.94$ & $\begin{array}{l}\text { Oblate } \\
\text { spheroidal }\end{array}$ & 3-porate & $9.09 \times 6.55$ & Reticulate & 6.13 & $1.68 / 1-2$ \\
\hline $\begin{array}{l}\text { Hibiscus vitifolius } \\
\text { Linn. }\end{array}$ & $151.16 \times 149.45$ & $\begin{array}{l}\text { Oblate } \\
\text { spheroidal }\end{array}$ & Polypantoporate & $6.74 \times 6.74$ & Reticulate & 24.85 & $4.54 / 3$ \\
\hline $\begin{array}{l}\text { Malwa parviflora } \\
\text { Linn. }\end{array}$ & $74.95 \times 72.48$ & $\begin{array}{l}\text { Oblate } \\
\text { spheroidal }\end{array}$ & Polypantoporate & $2.94 \times 2.94$ & Reticulate & 8.52 & $5.25 / 4$ \\
\hline Sida acuta Burm.f. & $87.78 \times 84.41$ & $\begin{array}{l}\text { Oblate } \\
\text { spheroidal }\end{array}$ & 6-7 pantoporate & $5.12 \times 3.87$ & Reticulate & 5.62 & $2.02 / 6$ \\
\hline $\begin{array}{l}\text { Sidar cordata } \\
\text { (Burm.f.) Borss. }\end{array}$ & $71.94 \times 70.68$ & $\begin{array}{l}\text { Oblate } \\
\text { spheroidal }\end{array}$ & 6-7 pantoporate & $4.00 \times 3.68$ & Reticulate & 5.68 & $1.68 / 7$ \\
\hline
\end{tabular}



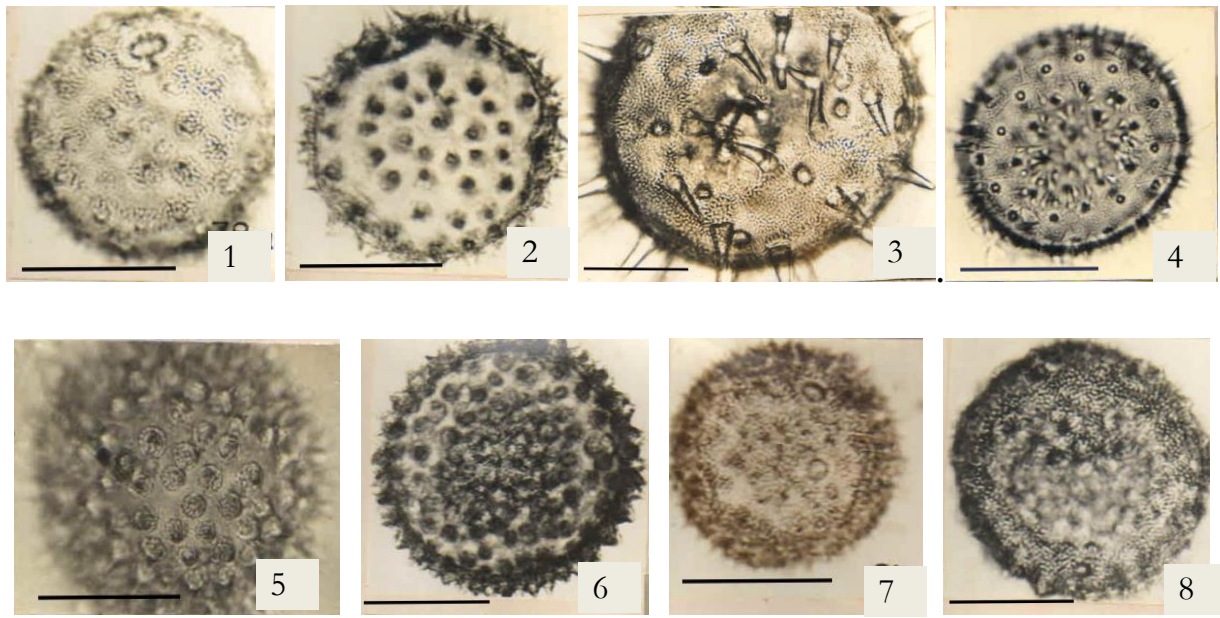

Figs. 1-8. Acetolysed pollen grains. 1-2. Abutilon indicum, 3. Hibiscus vitifolius, 4. Malva parviflora, 5. Malvastrum coromandelianum, 6. Sida acuta, 7. Sida cordata, 8. Sida cordifolia.

Sida cordata roots are used as diuretic, astringent, stomachic, febrifuge and demulcent and seeds are used as a laxative (Shah 2017). It has 6-7 pantoporate pollen grains with pollen size $71.94 \times$ $70.68 \mu \mathrm{m}$ (Fig. 7).

Sida cordifolia plant is analgesic and antiinflammatory. It is used as tonic which effects the nervous system and provides relief from anxiety (Jain et al., 2011). It has 3-pantoporate pollen grains with semitectate reticulate exine (Fig. 8). Jain \& Nanda (1966-67) reported the pollen grains for this species as spheroidal and cryptoaperturate whereas Selling (1946-47) recorded 3-porate and oblate spheroidal to suboblate shaped pollen grains.

Detailed pollen morphology has been of considerable help in preparing key to the identification of the species as follows:

\section{Key to identification of investigated species}

1a. Pollen grains inaperturate...Malvastrum coromandelianum 1b. Pollen grains aperturate

2a. Pollen grains 3 -porate

3a. Exine reticulate............Abutilon indicum

3b. Exine semitectate .......... Sida cordifolia

2b. Pollen grains 6-7 porate

4a. Pollen size $87.74 \times 84.41 \mu \mathrm{m}$.......Sida acuta

4b. Pollen size $71.94 \times 70.68 \mu \mathrm{m}$......Sida cordata

2c. Pollen grains polypantoporate

5a. Pollen size $151.16 \times 149.45 \mu \mathrm{m} . .$. Hibiscus vitifolius

5b. Pollen size $87.74 \times 84.41 \mu \mathrm{m}$....Malva parviflora

The pollen grains of the presently studied species are echinate in nature which supports the earlier reports by Perveen \& Qaiser (2009). The spines in the family Malvaceae are isolated in nature and stand conspicuously apart. Pollen size, number of apertures, spine characteristics and exine patterns help in accessing the evolutionary level of any taxa. As reported by Karna Mallick (2017) the circular, echinate, large and triporate pollen which are recorded in taxa of Malvaceae are primitive ones. Earlier Vaidhya (2005) considered the triporate pollen grains as most primitive one.

\section{Conclusion}

The study reveals morphologically differentiating characters in the pollen of presently studied taxa. It is concluded that palynological markers are useful in the identification and classification of the plant taxa.

\section{References}

1. Adekanmbi OP, "Pollen grains of Asteraceae and Analogous echinate grains", Internatinal Journal of Botany, 5.4 (2009): 295-300. Print

2. Bates DM, "Generic relationships in the Malvaceae, tribe Malveae", Gentes Herbarum, 10 (1968): 117-135. Print

3. Bera SK, Basumatary SK and Dixit S, "Studies on pollen morphology and phenological characteristics of some economically important arborescent taxa of tropical forest, lower Brahmaputra valley, Assam, North East India”, Journal of Palynology, 43 (2007) : 119. Print

4. Bibi N, Hussain M and Akhtar N, "Palynological studies of some cultivated species of genus Hibiscus from North west Frontier Province (N.W.F.P.) of Pakistan", Pakistan Journal of Botany, 40.4 (2008) : 1561-1569. Print

5. Erdtman G, "Pollen morphology and plant taxonomy of Angiosperm", In Introduction to Palynology, Waltham Mass Stockholm (1952). Print

6. Erdtman G, Bergland B and Praglowski J, " $A n$ Introduction to a Scandinavian Pollen Flora", Vol. 1 Almqvist and Wiksell, Stockholm (1961). Print

7. Fryxell PA, "Generic relationships of Decaschistia (Malvaceae) and the description of a new tribe, 
Decaschistieae", American Journal of Botany, 62 (1975): 172-175. Print

8. Fryxell PA, "Malvaceae of Mexico", Systematic Botany Monograph, 25 (1988): 1-255. Print

9. Hutchinson J, "The genera of flowering plants (Angiospermae) Dicotyledones", Vol. II. p. 659. London: Clarendon Press (1967). Print

10. Jain A, Choubey S,Singour PK, Rajak H and Pawar RS, Sida cordifolia (Linn) -An overview", Journal of Applied Pharmentical Science, 01.02 (2011) : 23-31. Print

11. Jain RK and Nanda S, "Pollen morphology of some desert plants of Pillani Rajasthan", Palynological Bulletin, 2 \& 3 (1966-67): 56-59. Print

12. Karna (Mallick) P, "Palynological Studies on Ten Species of Angiosperms from Nepal", Internatinal Journal of Applied Sciences and Biotechnology, 5.3 (2017): 361-365. Print

13. Keshavarzi M, Abassian S and Sheidai M, "Pollen morphology of the genus Clypeola (Brassicaceae) in Iran”, Phytologia Balcanica, 18.1 (2012): 17-24. Print

14. Krebs G, "Taxonomische Untersuchungen in der Subtribus Malvinae", Feddes Repert, 105 (1994 a): 718. Print

15. Krebs G, "Taxonomische Untersuchungen in der Subtribus Malvinae II, Dinacrusa", Feddes Repert, 105 (1994 b): 299-315. Print

16. La Duke JC and Doebley JA, "Chloroplast DNA based phylogeny of the Malvaceae", Systematic Botany, 20 (1995): 259-271. Print

17. Naggar SM, "Pollen Morphology of Egyptian Malvaceae: An Assessment of Taxonomic Value", Turkish Journal of Botany, 28 (2004): 227-240. Print

18. Nair PKK, "Pollen grains of Western Himalayan plants", Asia monograph no. 5 India (1965). Print

19. Nair PKK, "Essentials of Palynology", Asia Publishing House Bombay (1966). Print

20. Perveen A, "A contribution to the pollen morphology of the family Gramineae", World Applied Science Journal, 1 (2006): 60-65. Print

21. Perveen A and Qaiser M, "Pollen flora of Pakistan1.Malvaceae: Dombeyoideae- LXII". Pakistan Journalof Botany, 14 (2009): 491-494. Print
22. Perveen A, Siddiqui S, Fatima A and Qaiser M, "Pollen flora of Pakistan-1.Malvaceae", Pakistan Journal of Botany, 26.2 (1994): 421-440. Print

23. Rao AR and Shukla P, "Pollen flora of Upper Gangetic Plains, Indian pollen spore flora Vol. I", Today and Tommorow printers and Publishers, New Delhi (1975). Print

24. Reitsma $T$, "Suggestions towards unification of description terminology of angiosperm pollen grains", Review of Palaeobotany and Palynology, 10 (1970): 39-60. Print

25. Samuel AJ, Mohan S, Chellappan DK, Kalusalingam A and Ariamuthu S, "Hibiscus vitifolius (Linn.) root extracts shows potent protective action against antitubercular drug induced hepatotoxicity", Journal of Ethnopharmacology, 141.1 (2012): 396-402. Print

26. Sanghai DB, Kumar SV, Srinivasan KK, Aswatharam $\mathrm{HN}$ and Shreedhara CS, "Pharmacognostic and phytochemical investigation of the leaves of Malvastrum coromandelianum (L.) Garcke”, Ancient Science of Life, 33.1 (2013): 39-44. Print

27. Selling OH, "Studies in Hawaiian Pollen Statistics, Part I and IT", Bishop Museum Publ. Honolulu, Hawaii (1946-47). Print

28. Shah NA, Khan MR and Nigussie D, "Phytochemical investigation and nephroprotective potential of Sida cordata in rat", BMC Complementary and Alternative Medicine, 17 (2017): 388. Print

29. Shaheen N, Khan MA, Hayat MQ and Yasmin G, "Pollen morphology of 14 species of Abutilon and Hibiscus of the family Malvaceae (sensu stricto)", Journal of Medicinal Plants Research, 3.11 (2009): 921-929. Print

30. Vaidhya BL, "Study of Cytogenetic Diversity in Ranunculaceae", (Unpublished doctoral dissertation). Central Department of Botany, Institute of Science and Technology, Tribhuvan University, Kirtipur, Kathmandu, Nepal (2005). Print

\section{Cite this article as:}

Paramjeet Cheema. Palynological studies on some medicinal mallows from Punjab, India. Annals of Plant Sciences 7.3 (2018) pp. 2166-2169.

doi $\mathrm{http}: / / \mathrm{dx}$.doi.org/10.21746/aps.2018.7.3.13 